\title{
The Development of E-Learning in the Philosophy of Tri Hita Karana Concept on the Natural Science Course in PGSD Study Program, FIP UNDIKSHA
}

\author{
Tri Agustiana ${ }^{1}$, Luh Sri Surya Wisma Jayanti ${ }^{1}$ \\ ${ }^{1}$ Universitas Pendidikan Ganesha, Indonesia \\ *Corresponding author.Email: igede.margunayasa@undiksha.ac.id
}

I Gede Margunayasa ${ }^{1}$, I Made Citra Wibawa ${ }^{1}$, Nyoman Kusmariyatni ${ }^{1}$, I Gusti Ayu

\begin{abstract}
The problems experienced by natural science lecturers in the PGSD study program include: (1) there was no e-learning device containing the Tri Hita Karana concept in the Science course in PGSD Study program, (2) the e-learning learning system for the natural Science course in PGSD study program was not in accordance with online learning guidelines, and (3) PSGD study program lecturers in general did not understand about Undiksha's online learning. For this reason, the aimed of this research was: (1) to develop e-learning administrations in the philosophy of Tri Hita Karana concept in natural science course in PGSD Study program, (2) to determine the quality of e-learning administrations with the Tri Hita Karana concept on natural natural science course in the PGSD Study program, and (3) to determine the effectiveness of e-learning administrations containing with the Tri Hita Karana concept on the natural Science course in PGSD Study program, FIP Undiksha. This research was conducted in PGSD Study program, Pendas FIP Undiksha. This research was research and development in the field of education using the 4D model, namely Define, Design, Develop and Disseminate, modification of the 4D model from Thiagarajan et al. (1974). Define was an activity to collect various information needed (needs assessment). Design was an activity to design an initial product or a draft of elearning learning administration in the philosophy of Tri Hita Karana concept on the natural science course. Develop was the activity of developing a product or device. Disseminate was an activity to prepare research reports and articles (booklets) for publication. This research was a multiyear research which was lasted for two years. In the first year, the define, design, expert validation, legibility test, and limited device testing (develop step) were carried out. In the second year, an extensive model trial was conducted (the develop step) and the results were disseminated (the disseminate step).
\end{abstract}

Keywords: e-Learning, Tri Hita Karana

\section{INTRODUCTION}

Currently the world is faced with the development of information and communication technology which is very fast and penetrates the various aspects of human life. This new era is often known as the Industrial Revolution 4.0. This era is faced with a phenomenon of disruption, which means a fundamental change [1]. The impact of the development of information and communication technology is very large and fundamental in all fields, such as government, administration, economy, education, and others. In the field of government, now the term e-government has begun to be introduced, in the economic field most people are familiar with the terms ecommerce, e-marketing, and several years ago the government launched the e-KTP program. Likewise, it is happened in the field of education. In recent years, many teachers, lecturers and practitioners have used information and communication technology to deliver learning materials. A popular term used in education is elearning. Currently, several leading schools already have facilities such as computer laboratories and internet networks that support the implementation of e-learning. This is proof that the world of education is also not from the changes due to the revolutionary era 4.0.

Higher education should not be left behind with this but must be able to respond to this progress and even have to be able to prepare for the era of the industrial revolution 4.0. Moh. Nasir [2] at that time as 
Kemenristekdikkti stated that higher education in Indonesia must make changes to the 'disruptive technology era' and play a role in filling the country's development [1]. The use of information and communication technology such as e-learning, one of which is through Web-based learning will bring significant changes both in terms of the education system to be developed, the material to be delivered, how the instructional and learning processes will be carried out, and the obstacles that will be faced both by students, lecturers, and education providers. The use of media such as e-learning in a learning process is expected to be an alternative to solve the problem of independent learning that was often encountered because the use of this media allows teaching a student to seek and study broader knowledge in the internet world so as to give rise to student creativity in learning science.

In addition, with this e-learning, lecturers were able to create material content that will be delivered easily and of course effectively. Lecturers were also greatly helped by e-learning, if the lecturer was unable to attend when the offline (face-to-face) lecture was taking place. So, we can be sure that the teaching and learning process will be facilitated by the existence of this e-learning.

Undiksha as a LPTK has actually responded to the program from the Ministry of Research, Technology and Higher Education by developing an e-learning system, it's just that the development of learning administrations has not been optimal. The results of self-reflection that: (1) there was no e-learning administrations containing the Tri Hita Karana concept in the natural science course in PGSD Study program, (2) the e-learning learning system for natural science course in PGSD Study program was not in accordance with online learning guidelines, and (3) the lecturers of the PSGD study program in general did not understand about Undiksha's online learning / elearning. Even though e-learning can greatly assist lecturers in delivering material that was more practical and easily accessible to students [3]. For this reason, in this research, researchers were interested in developing e-learning administrations in natural science course at PGSD. E-Learning in this research was a type of Blended E-Learning, where there would be face-to-face methods in class and also online lectures. Lecturers and students can take advantage of e-learning in the learning process, in the form of access to online teaching materials, learning videos, online discussions, online assignments, and online exams.

The development of information and communication technology had a significant impact on several aspects of people's lives. One of them was in the aspect of education. People can easily get knowledge or insight from the internet. The number of sources spread on the internet allows people to access them via smart phones or gadgets. Now Indonesia was faced with the challenges of the 4.0 industrial revolution era. Not only the economic, social and technological sectors but the education sector now inevitably has to adapt to this era. This development has begun to be used by several universities in Indonesia in the implementation of their education programs. This program was known as an online lecture program or elearning / online learning system.

Undiksha already has a system for online learning or e learning. This system can be used by lecturers from all faculties at Undiksha. Some lecturers from PGSD Study Faculty of Education (FIP) study program have also used this system in the lecture process, but the numbers were not too many and only for a few courses. Some of the problems faced by natural science lecturers in PGSD Study program include: (1) there was no e-learning administrations containing the Tri Hita Karana concept in the natural science course in PGSD study program, (2) the e-learning learning system for the Science course in PGSD study program was not yet in accordance with online learning guidelines, and (3) the lecturers of the PSGD study program in general do not understand about Undiksha's online learning / e-learning. For this reason, research on the development of e-learning administrations with the Tri Hita Karana concept in science course in PGSD study program was very important. After the e-learning learning administrations containing the Tri Hita Karana concept has been developed, it was followed by an application to the elearning system on the web. With this research, it was hoped that lecturers will have examples of e-learning administrations containing the Tri Hita Karana concept, and can apply e-learning learning in lectures at the PGSD study program. Thus, students will be more interested in understanding natural science material, and will be more motivated to take lectures that can be done anytime and anywhere, and students' information technology (IT) skills will be even better and very useful in the current era of industrial revolution 4.0

The objectives of this research were as follows: (1) to develop e-learning administrations with the Tri Hita Karana concept in natural science course in PGSD study program. (2) to determine the quality of e-learning administrations containing the Tri Hita Karana concept in natural science course in PGSD Study program. (3) This was to determine the effectiveness of e-learning learning administrations containing the Tri Hita Karana concept in natural science course in PGSD study program.

\section{METHODS}

This research was conducted in PGSD study program, Pendas FIP Undiksha. The type of this research was research and development in the field of education by using the 4D model, namely Define, Design, Develop and Disseminate, modification of the 4D model from Thiagarajan et al. (1974). Define was an activity to collect various information needed (needs assessment). Design was an activity to design an initial product or a 
draft of an e-learning administration with the Tri Hita Karana concept in natural science course. The eadministrations to be developed include RPS, materials, Power Point materials, discussion materials and assignments, learning videos, and system development in Undiksha e-learning. Develop was the activity of developing a product or device. Disseminate was an activity to prepare research reports and articles (booklets) for publication. This research was a multiyear study, which lasted for two years. In the first year, the define, design, expert validation, legibility test, and limited device testing (develop step) were carried out. In the second year, an extensive model trial was conducted (the develop step) and the results were disseminated (the disseminate step).

\subsection{Needs Analysis (Define Step)}

Needs analysis was carried out through literature and field studies. Literature and field studies were carried out to collect information that could be used as material for designing a draft of e-learning administrations containing the Tri Hita Karana concept in natural science course. The aspects investigated in the literature study were as follows.

1) Analysis of content standards in natural science course in PGSD study program. 2) From these essential natural science concepts, the labels, definitions, types, critical and variable attributes, positions (super ordinate, ordinate, and subordinate) were determined. 3) Creating a concept map that describes the relationship between concepts and concept positions. 4) Describe learning outcomes into learning indicators in Elementary natural science course. 5) This indicator was used to design the items.6) Task analysis concerns the tasks that will be carried out by lecturers and students. 7) Analysis of the theory and research findings related to e-learning administrations containing the Tri Hita Karana concept.

On the other hand, this field research was carried out in PGSD study program, Pendas Department, FIP Undiksha. The aspects investigated in this research were as follows:

1) Analysis of learning administrations used by natural science lecturers at PGSD, including syllabus, semester learning plans, science learning outcomes tests. 2) Analysis of student characteristics, including academic ability, working together, conducting natural science investigations and practicum, communicating written and verbally, and character values. 3) The analysis of the learning context includes an analysis of the environment in which e-learning learning administrations were implemented with the Tri Hita Karana concept in the natural science course developed in this research.

Meanwhile, analysis of the Tri Hita Karana contexts relevant to the PGSD natural science material was carried out by interviewing community leaders who understand Tri Hita Karana's philosophy, including natural science lecturers of PGSD study program. Tri Hita Karana's philosophical contexts that were identified from the results of interviews with community leaders were then selected which were relevant to the natural science material in the PGSD study program.

\subsection{Designing a Draft of E-learning Administrations with the Tri Hita Karana Concept in Natural Science Course (Design Step)}

The results of the literature research and field studies were used as material to design a draft of e-learning administrations containing the Tri Hita Karana concept in natural science course. This learning administrations was supported by a semester learning plan (RPS), materials, PPT teaching materials, discussion sheets, learning videos, learning evaluation sheets, and e-learning designs on SIAK.

\subsection{Expert Validation of the Draft of E- Learning Administrations with the Tri Hita Karana Concept in Natural Science Subjects}

The draft of the e-learning administrations containing the Tri Hita Karana concept in the natural science course that had been designed is then validated by three lecturers to obtain input from experts. The selection of lecturers was based on expertise in the research of elementary in natural science content, in the field of learning technology, and in the field of local wisdom Tri Hita Karana.

\subsection{Readability Test of E-Learning Administrations with the Tri Hita Karana Concept in Natural Science Subject}

Before the E-learning administrations containing the Tri Hita Karana concept in the natural science course was applied, the administrations were read by ten (10) students. The aim was to determine the perception or interpretation of the meaning of the writing in the elearning administrations containing the Tri Hita Karana concept in the natural science subject (legibility test).

\subsection{Limited Trial of E-Learning Administrations with the Tri Hita Karana Concept in Natural Science Course (Develop Step)}

The draft of the e-learning administrations contained the Tri Hita Karana concept in the revised natural science course based on input from experts and the results of the legibility test and then tested on a limited basis. This limited trial was conducted in one class in the PGSD 
study program. This limited trial used a quasi preexperimental design: "The One Group Pretest-Posttest Design." However, before the limited test was carried out, the e-learning administrations compiled were inputted into the e-learning system owned by Undiksha. Undiksha's e-learning system uses LMS Moodle [4].

\section{FINDINGS AND DISCUSSION}

This research was conducted in PGSD Study program, Pendas FIP Undiksha. This research is a research and development (research and development) in the field of education using the 4D model, namely Define, Design, Develop and Deseminate, a modification of the 4D model from Thiagarajan et al. (1974). Define was an activity to collect various information needed (needs assessment). Design was an activity to design an initial product or a draft of an e-learning learning tool with the Tri Hita Karana concept in natural science course. The e-learning tools to be developed include RPS, materials, Powerpoint materials, discussion materials and assignments, learning videos, and system development in Undiksha e-learning. Develop was the activity of developing a product or device. Disseminate was an activity to prepare research reports and articles (booklets) for publication. This study was a multiyear study, which lasted for two years. In the first year, the define, design, expert validation, legibility test, and limited device testing (develop step) were carried out. In the second year, an extensive model trial was conducted (the develop step) and the results were disseminated (the disseminate step). The following shows the results of the first year research.

Needs analysis was carried out through literature study and field studies. Literature and field studies were carried out to collect information that can be used as material for designing a draft of e-learning administrations containing the Tri Hita Karana concept in natural science course. The aspects investigated in the literature were as follows. (1) Analysis of content standards in natural science course in PGSD Study program. (2) From these essential science concepts, labels, definitions, types, critical and variable attributes, positions (superordinate, ordinate and subordinate) were determined. (3) Creating a concept map that illustrates the relationship between concepts and concept positions. (4) Describe learning outcomes into learning indicators in Elementary natural science course. (5) This indicator was used to design the items. (6) The task analysis concerns the tasks to be carried out by lecturers and students. (7) Analysis of the theory and research findings related to e-learning administrations containing the Tri Hita Karana concept.

On the other hand, this research was conducted in the PGSD study program, Pendas Department, FIP Undiksha. The aspects investigated in the research were as follows. (1) Analysis of the administrations used by science lecturers at PGSD, including syllabus, semester learning plans, natural science learning outcomes tests. (2) Analysis of student characteristics, including academic ability, cooperation, conducting science investigations and practicum, writing and oral communication, and character values. (3) The analysis of the learning context includes an analysis of the environment in which e-learning administrations were implemented with the Tri Hita Karana concept in the natural science course developed in this research.

The following are 3 natural science course that would be made into e-learning administrations:

Table 1. 3 natural science course that would be made into e-learning administrations

\begin{tabular}{|c|l|l|c|c|c|}
\hline $\begin{array}{c}\text { N } \\
0\end{array}$ & Course & $\begin{array}{l}\text { Course } \\
\text { Code }\end{array}$ & $\begin{array}{c}\text { Curri- } \\
\text { culum }\end{array}$ & SKS & $\begin{array}{c}\text { Semes- } \\
\text { ter }\end{array}$ \\
\hline 1 & $\begin{array}{l}\text { Konsep } \\
\text { Dasar IPA } \\
\text { SD }\end{array}$ & $\begin{array}{l}\text { GSDS12 } \\
0102\end{array}$ & 2020 & 3 & 1 \\
\hline 2 & $\begin{array}{l}\text { IPA SD } \\
\text { Terin- } \\
\text { tegrasi }\end{array}$ & $\begin{array}{l}\text { GSD193 } \\
05\end{array}$ & 2019 & 3 & 3 \\
\hline 3 & $\begin{array}{l}\text { Pendi- } \\
\text { dikan IPA } \\
\text { SD }\end{array}$ & $\begin{array}{l}\text { GSD153 } \\
\text { SD }\end{array}$ & 2016 & 3 & 5 \\
\hline
\end{tabular}

The results of the literature research and field studies were used as material to design a draft of e-learning administrations containing the Tri Hita Karana concept in natural science course. This administration was supported by e learning guides, syllabus, semester learning plans (RPS), materials, PPT teaching materials, discussion sheets, learning videos, learning evaluation sheets, and e-learning designs on SIAK. The following was a guide to e-learning at PGSD. To maximize the PGSD e-learning lectures for the odd semester in the academic year 2020-2021 through the Undiksha elearning system, here are some things that need to be conveyed:

1. Online learning (e-learning) applies equally to PGSD Singaraja and PGSD Denpasar, for both lecturers and students.

2. E-learning could be accessed via sso.undiksha.ac.id / elearning.undiksha.ac.id.

3. Online learning was used to follow the PEDATI pattern. PEDATI was short for Online Learning in Higher Education. PEDATI can also be said to be an acronym for Learn - DAlami - Apply and evaluate. Implemented through students studying the material through PDF, PPT, or video provided / accessing e-resources, then actively exploring through discussion forums / video conferences, then applying through creating assignments or creating projects, and 
ending with taking an evaluation in the form of exams, UTS (mid semester test) and UAS (final semester test).

4. E-learning courses held by the PGSD study program were as shown in Table 1. Apart from these, the MPK and MK courses were not the responsibility of the PGSD study program.

5. Each course was set up in 16 meetings according to study guidelines such as the following schedule.

6. For the discussion forum, it was opened and closed automatically and takes place according to the day of the course schedule and was only active that day every week. Students could not access other than the scheduled day. Opened from 00.00 and closed automatically at 23.59. Students take part in discussion forums according to their class. The more participation in the discussion, the better the value of student attitudes and participation would be.

7. If the answers to the discussions / assignments were the same between one student and another, then the student was given a score of 30 .

8. For the Video Conference (VC), it would take place 4 times for one course, arranged according to the design made, but if it changes, it remains on the basis of an agreement between lecturers and students. The video conference link would be given by the lecturer of the course to the coordinator in each class. During the video conference, students must wear PGSD uniforms.

9. For Assignments, would be opened automatically on Monday every week starting at 00.00 and closed automatically on the following Sunday at 23.59. Guidelines for assignment assessment were made by each lecturer. Students access and send assignments according to their group class by WA (Whatsapp) .

10. The UTS (mid semester test) and UAS (final semester test) schedule were in accordance with the schedule, and if there were changes, information would be given to the coordinator in each class. Guidelines for assessing the exam were made by each lecturer. Students accessed and sent exams according to their group class by WA (Whatsapp).

11. Each class is required to create a group class by WA (Whatsapp) for one course and must invite the teaching lecturers to join. This Whatsapp (WA) group was an effective means of communication. Try to make efforts to name the Whatsapp (WA) group according to this format: Name of MK _ Class, for example Integrated IPA_3A.

The draft of the e-learning administrations contained Tri Hita Karana concept in the revised on natural science course based on input from experts and the results of the legibility test and then tested on a limited test. This limited trial was conducted in one class in the PGSD study program. This limited trial used a quasi preexperimental design: "The One Group Pretest-Design." However, before the limited test was carried out, the elearning tools compiled were inputted into the e-learning system owned by Undiksha. Undiksha's e-learning system uses LMS Moodle [4].

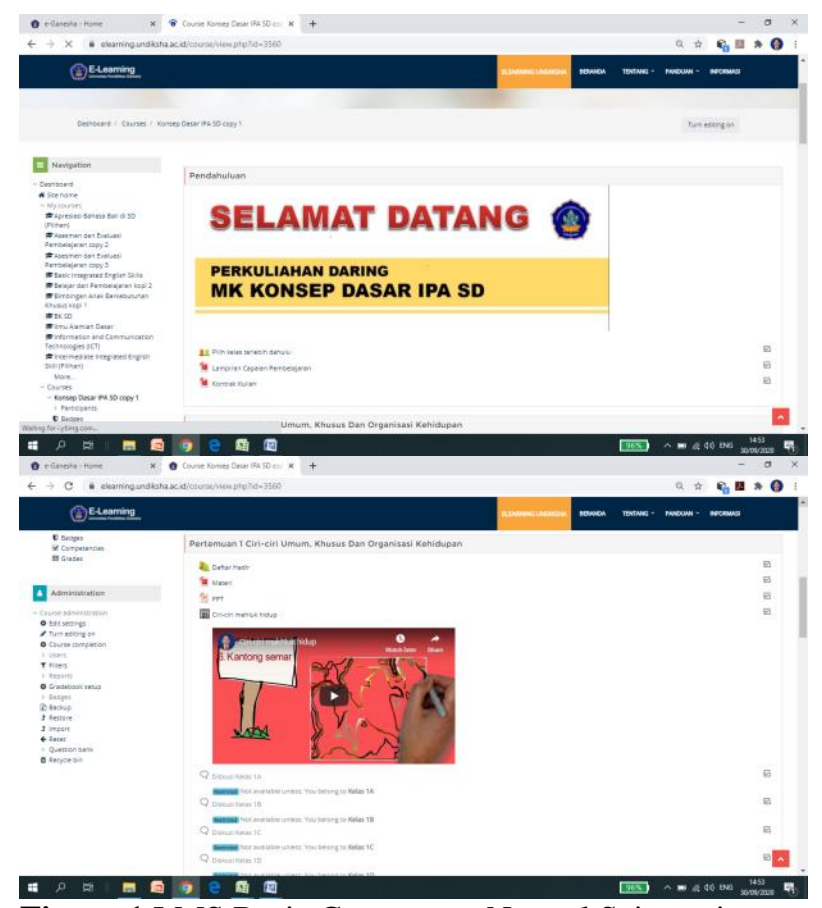

Figure 1 LMS Basic Concept on Natural Science in Elementary

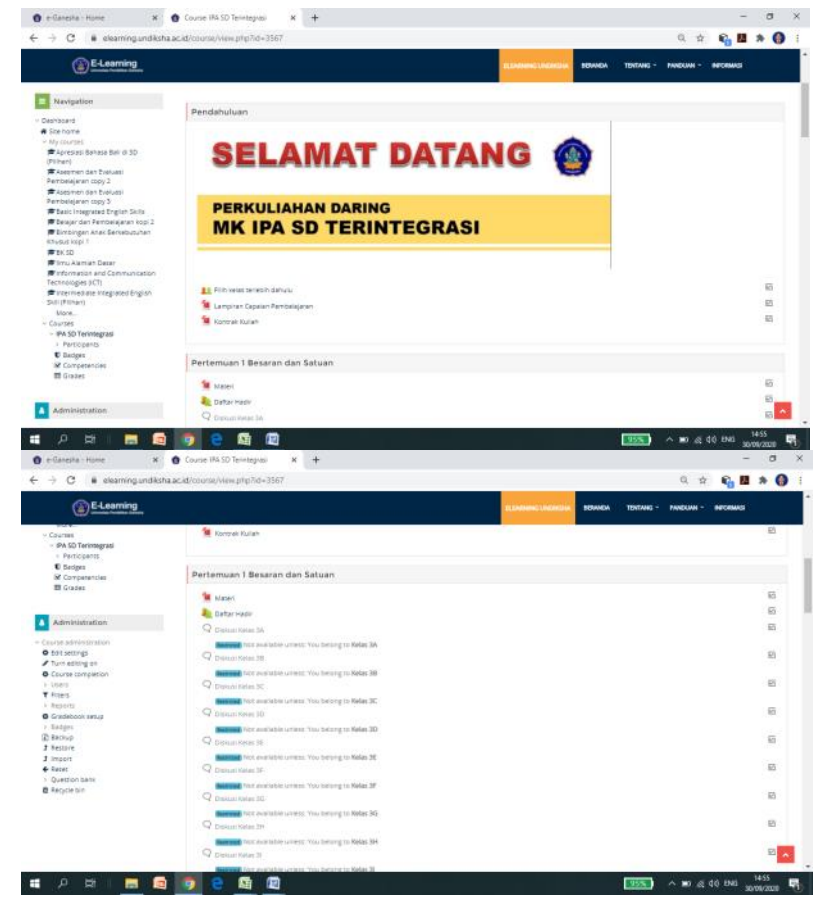

Figure 2 LMS Basic Concept on Natural Science Integrated in Elementary 


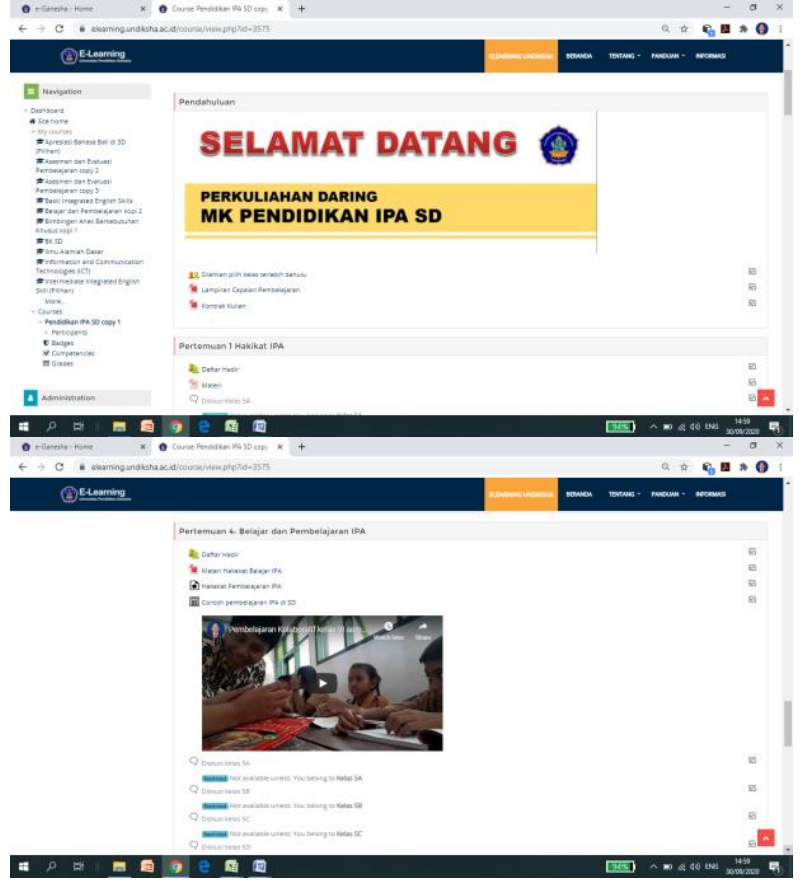

Figure 3 LMS on Natural Science of Education in Elementary

\section{DISCUSSION}

The 21 st century was known as the knowledge era, the knowledge-based economy, the information technology century, globalization, the industrial revolution 4.0, and so on. In this century, there were very rapid changes in all aspects of life. In order to keep up with developments in the 21 st century, 21 st century skills need to be developed which include: critical thinking and problem solving, creativity and innovation, collaboration, and communication. In addition, one must also master technology, information and communication literacy [5].

The 21st century learning is learning that provides 21st century skills or skills to students known as $4 \mathrm{C}$, namely: (1) Communication; (2) Collaboration; (3) Critical Thinking; and (4) Creativity [6]. To fill the demands of 21 st century education, a learning method, namely blended learning, can be applied. Blended learning is a learning model that combines face-to-face learning with e-learning [7]. E-Learning is an application of technology in the field of education by utilizing the internet to carry out teaching and learning activities online. By utilizing e-learning, the interaction between students and teaching materials / materials, teachers, and other students would become easier. Students could discuss with each other or share opinions on topics or problems provided by the teacher on e-learning. In addition to discussions, students could also access teaching materials or evaluation questions which could only be accessed once and within a certain period of time. If students follow e-learning well, then automatically the 21 st century skills, namely communication, collaboration, critical thinking and problem solving, as well as creation and innovation would be achieved without even realizing it. Apart from being online, learning also needs to be carried out face-to-face both between teachers and students and between students and other students. It aimed to maintain the intensity of students' socialization with their social environment. Therefore, blended learning was very suitable to be applied to fill the demands of education in the $21 \mathrm{st}$ century.

Technology is the most basic thing in the era of the industrial revolution 4.0. The era of the industrial revolution 4.0 was marked by increased connectivity, interaction and development of digital systems, artificial intelligence, virtual and the use of cyber technology and automation technology in all areas of human life. Most of the work is done automatically by technology without the need for a lot of human labor. This of course can add to the value of efficiency and reduce production costs. One sector that must prepare itself and adapt to technology and global challenges is education. Educational institutions must prepare a new orientation and literacy that previously only read, write, and turn mathematics into reading, writing, mathematics, data literacy, technology, and human resources [8]. Therefore, the use of technology in education must be optimized through the application of e-learning or blended learning in teaching and learning activities.

E-learning is learning that enables online teaching and learning activities. E-learning can be done from anywhere and anytime as long as there is an internet connection. The learning success of students in elearning is determined by the students themselves. The more active his efforts in following e-learning, the optimal results will be obtained and vice versa. Blended learning is a method that combines e-learning with conventional (face-to-face) learning [7]. By combining the two learning methods, the technology that is the demand for the 4.0 industrial revolution era can be applied without neglecting the need for social interaction or face-to-face activities that are needed by students in class.

\section{CONCLUSSION}

This research had resulted in: (1) e-learning learning tools containing the Tri Hita Karana concept in the Science course in PGSD study program, (2) the quality of e-learning administrations containing the Tri Hita Karana concept in natural science course in PGSD Study Program were very good, and (3) the e-learning administrations contained the Tri Hita Karana concept in the science course in PGSD study program which was developed to improve student learning outcomes effectively. 


\section{REFERENCES}

[1] L. P. P. Mahadewi, I. M. Tegeh, G. A. P. P. Sari, Pengembangan Konten E-Learning Prakarya Pada Era Revolusi Industri 4.0, Mimbar Ilmu 24(2) (2019) 194-200.

[2] M. Nasir, Pengembangan Iptek dan Pendidikan Tinggi di Era RevolusiIndustri 4.0, 2018. Retrieved February 25, 2020, from www.ristekdikti.go.id/pengembangan-iptek-danpendidikan-tinggi-diera-revolusi-industri-4-0.

[3] P. Astuti, Y. Hartono, Developing ICT-based teaching materials of English for Mathematics course, In Sriwijaya University Learning and Education International Conference 2(1) (2016) 863-878.

[4] UPT TIK, Panduan Penggunaan Elearning Universitas Pendidikan Ganesha, Singaraja, 2017.

[5] I. W. Redhana, Mengembangkan Keterampilan Abad ke-21 dalam Pembelajaran Kimia, Jurnal Inovasi Pendidikan Kimia 13(1) (2019) 2239-2253.

[6] Sugiyarti, Lina, Alrahmat Arif, Mursalin, Prosiding Seminar dan Diskusi Nasional Pendidikan Dasar 2018, Tema: Menyongsong Transformasi Pendidikan Abad 21, Universitas Negeri Jakarta, 2018.

[7] D. N. Wardani, A.J. Toenlioe, A. Wedi, Daya tarik pembelajaran di era 21 dengan Blended Learning, Jurnal Kajian Teknologi Pendidikan 1(1) (2018) 1318.

[8] D. Lase, Pendidikan di Era Revolusi 4.0, Jurnal Sundermann 1(18) (2019) 28-23. 